Nigerian Journal of Technology (NIJOTECH)

Vol. 35, No. 2, April 2016, pp. 349 - 359

Copyright@ Faculty of Engineering, University of Nigeria, Nsukka,

Print ISSN: 0331-8443, Electronic ISSN: 2467-8821

www.nijotech.com

http://dx.doi.org/10.4314/njt.v35i2.16

\title{
ASSESSMENT OF MILLENNIUM DEVELOPMENT GOAL 7 IN THE NIGER DELTA REGION OF NIGERIA VIA EMISSIONS INVENTORY OF FLARED GAS
}

\author{
S. O. Giwa ${ }^{1,}{ }^{*}$, C. N. Nwaokocha ${ }^{2}$ and A. T. Layeni ${ }^{3}$

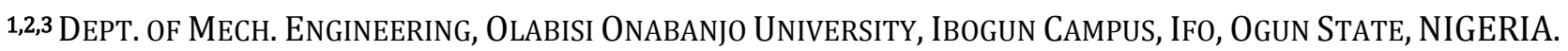 \\ E-mail addresses: ${ }^{1}$ sologiwa2002@yahoo.com, ${ }^{2}$ collinsnwaokocha@gmail.com, ${ }^{3}$ yomilayeni@gmail.com.
}

\begin{abstract}
Emissions released into the atmosphere from gas flaring in the Niger Delta Region (NDR) of Nigeria have adversely affected the environment and well-being of the inhabitants. This present study aimed at employing the emission inventory of flared gas in this region to assess the level of achievement of Millennium development goal (MDG) 7 with respect to sustainable environment. Greenhouse gas (GHG) and black carbon (BC) inventory of the region was estimated from gas flared data sourced from Nigeria National Petroleum Corporation using empirical formula and emission factors obtained from literature. For the period in view (1990-2014), a total estimate of $1.80 \times 10^{9}$ tons of $\mathrm{CO}_{2}$ equivalent $\left(\mathrm{tCO}_{2}\right.$ e) was released into the atmosphere from the flaring of $555.74 \mathrm{Bcm}$ of gas. Relative uncertainty of the emission was between $-92.2 \%$ and $51.16 \%$. It was observed that the present (2014) quantity of emissions has reduced by $49.71 \%\left(3.61 \times 10^{7} \mathrm{tCO}_{2} \mathrm{e}\right.$ ) compared to the emissions $\left(7.26 \times 10^{7} \mathrm{tCO}_{2} \mathrm{e}\right.$ ) for the year 1990. The results showed that MDG-7 on environmental sustainability in the NDR is progressing well with considerable emission reduction achieved through increased utilization of gas in the country to reduce the volume of gas flared.
\end{abstract}

Keyword: Emissions inventory; greenhouse gas; black carbon; millennium development goals; Niger Delta; flared gas

Nomenclature

$\mathrm{bcm}=$ Billion cubic metretcm $=$ Trillion cubic metre

$\mathrm{tcf}=$ Trillion cubic feetW $/ \mathrm{m}^{2}=$ Watt per square metre

$\mathrm{km}^{2}=$ Kilometre square

mscf $=$ Million standard cubic feet

$\mathrm{mcm}=$ Million cubic metre

$\mathrm{scf}=$ Standard cubic feet

tons $=$ Tonnes

$\mathrm{tCO}_{2} \mathrm{e}=$ Tonnes of carbon dioxide equivalent

$\mathrm{GF}=\mathrm{Gas}$ flared

$\mathrm{GP}=$ Gas Produced

$\mathrm{EF}=$ Emission factor

$\mathrm{HV}=$ Heating value

$\mathrm{BC}=$ Black carbon

$\mathrm{GHG}=$ Greenhouse gas

$\mathrm{CH}_{4}=$ Methane

$\mathrm{N}_{2} \mathrm{O}=$ Nitrous oxide

$\mathrm{CO}_{2}=$ Carbon dioxide

$\mathrm{MW}=$ Molecular weight

$\mathrm{E}=$ Emissions

$\AA=$ Registered trademark

\section{INTRODUCTION}

Gas flaring is one of the combustion-related human activities that can lead to global warming and climate change, hence, it is of local and global concern. The act of gas flaring is one of the most demanding and important energy and environmental problems confronting the world. Atmospheric contaminants from gas flaring include oxides of nitrogen, carbon and sulphur, particulate matter, hydrocarbons and ash, photochemical oxidants, benzapryene, toluene, xylene and hydrogen sulphide $[1,2]$ which are released into the atmosphere in large quantities with adverse effects on the environment. The quantities of emissions from natural gas flaring depend on gas production, its composition, and the flare efficiency.

Nigeria is the sixth largest oil producer in the world with the seventh largest gas reserves in the world and the largest in Africa and is second only to Russia in gas flaring [3]. The Niger Delta is endowed with an estimated reserve of about 23 billion barrels of oil and 183 trillion cubic feet (tcf) of natural gas. Gas flaring

*Corresponding author Tel: +234-809-175-7240 
commenced right from the petroleum exploration in the Niger Delta region (NDR) of Nigeria in 1956 [4] and has been a contentious issue in Nigeria since the beginning of commercial exploitation of crude oil in the country. It has been reported that the estimated amount of gas flared in Nigeria in 2008 was 15.1 billion cubic metres (bcm) [5]. Gas flaring operation is still on-going in Nigeria despite government policies and international communities' pressure to put an end to it. Besides the huge annual financial (about US \$2.5 billion) loss for over five decades [6] of gas flaring, the environmental impact of this exercise is unquantifiable, overwhelming and far reaching.

Pollution of various types (soil, water, air, light, thermal, noise) from gas flaring in the NDR of Nigeria have been reported; which has physical, chemical, biological, atmospheric and soil effects on the area [2, 7]. Gas flaring has multifaceted impact on the environment, ecosystem, socio-economic and health of the residents of the area $[2,4,8]$. Most of the flaring take place close to communities and residents living near the gas flares complain of respiratory problems, skin rashes and eye irritations, as well as damage to plants due to acid rain $[2,4,9]$. It kills off crops such as cassava, a staple food in many African nations, which becomes malformed and rotten. The water systems, especially, surface water also become polluted and the fish die off. These effects are not only harmful for the environment, but impact negatively on the communities who farm and eat these fish. Many farmers have lost their livelihoods, and communities are suffering from lack of food due to the impacts of these obnoxious gases emitted through gas flaring activities [7]. It has been reported that life expectancy in the NDR is about 40 years due to the negative impact of gas flaring in the area $[8,10]$. The aforementioned have impoverished the people of this area and have grossly degraded the environment.

The impact of gas flaring on the global community in terms of GHG emissions is substantial due to the emission of 260 to 400 million tonnes per year of $\mathrm{CO}_{2}$ as a result of flaring about $150 \mathrm{bcm}$ of gas [11]. In fact, Nigeria's gas flaring activities account for about 25\% of Africa's GHGs [10]. The World Bank estimated that Nigeria gas flares contribute about 70 million metric tons of carbon dioxide emissions a year [9]. It also releases about 12 million tons of $\mathrm{CH}_{4}$, which is known to have higher warming potential than $\mathrm{CO}_{2}[12,13]$.

Gas flaring is likely one of the largest sources of Black Carbon (BC) emissions from the oil and gas sector. BC emissions are caused by incomplete combustion of fossil fuels, biofuels and biomass. $\mathrm{BC}$ is the most strongly light-absorbing component of particulate matter (PM). An aerosol rather than a greenhouse gas, it is the second largest climate forcer in today's atmosphere, following carbon dioxide with a net climate forcing of $+1.1 \mathrm{~W} / \mathrm{m}^{2}$ [14]. BC's contribution to global warming is approximately $70 \%$ of carbon dioxide's contribution. Although, $\mathrm{BC}$ remains in the atmosphere for only a few days, one gram of $\mathrm{BC}$ warms the atmosphere several hundred times more during its short lifetime than one gram of carbon dioxide does during 100 years [7]. $\mathrm{BC}$, as part of $\mathrm{PM}_{2.5}$, has adverse impacts on human health, ecosystems, climate and visibility. $\mathrm{BC}$ particles can penetrate into the human body through the lungs with inhalation, through the gastrointestinal tract with water and food contact, and through skin and mucosa [15].

Greenhouse gases $\left(\mathrm{CO}_{2}, \mathrm{~N}_{2} \mathrm{O}\right.$ and $\left.\mathrm{CH}_{4}\right)$ and $\mathrm{BC}$ are important component of the emissions from gas flaring activities. Both contribute significantly to global warming which leads to climate change. While greenhouse gas (GHG) emissions affect local, regional, national and international communities, and it is a long-lived climate forcer, the BC emissions affect local, regional and national communities, and are mainly a short-lived climate forcer. BC has recently been reported to have a global warming potential which is only second to that of $\mathrm{CO}_{2}$ [14]. $\mathrm{BC}$ is known to have a considerable effect on the climate, environment and public health.

Millennium Development Goals (MDGs) have been perceived as the world biggest promise to mankind, especially for Africa as a continent with a benchmark of 2015. It was birthed by United Nations as a result of series of meeting and conferences held at various international for a. MDG is a collection of developmental goals and targets committing about 189 countries and practically all of the world's main multilateral organisations to an unequalled attempt to reduce multi-dimensional poverty through global partnership. MDG is made of 8 goals supported by 18 quantifiable targets and 48 indicators through which progress can be measured. These goals are to (1) eradicate extreme poverty and hunger, (2) achieve universal primary education, (3) promote gender equality and empower women, (4) reduce child mortality, (5) improve maternal health, (6) combat HIV/AIDS, malaria, and other diseases, (7) ensure environmental sustainability and (8) develop a global partnership for development. These praiseworthy 
goals are expected to be achieved between the years 1990-2015.

Nigeria as a member of global committee of nations is part of the global race in achieving the MDGs. This led to developmental plans such as VISION 2010, NEEDS, 7-Points Agenda, VISION 20:2020, SURE etc. within the framework of MDG to serve as driving force to achieve these laudable projects. Several studies on MDGs attainment in Nigeria have been carried out with most of them reporting on Goals 1 to 6 and 8, and few on Goal 7 [16-22]. The focus of MDG 7 is to ensure environmental sustainability of which Targets 10 and 11 are often reported in literature with scarce report on Target 9 [17]. Out of the Targets of Goal 7, Target 9 with indicator 28 (carbon dioxide emissions (per capita) and consumption of ozone-depleting chlorofluorocarbons) which addresses the issue of emission in relation to sustainable environment [22] paints the true picture of happenings in the NDR of Nigeria as regard gas flaring.

The main aim of this study is to carry out emission inventory and analyses of gas flaring activities in the NDR of the Nigeria with the objective of assessing the efforts of the Nigerian government in achievement of sustainable development through MDGs, especially Goal 7.

\section{METHODOLOGY}

\subsection{Study Area}

The continuous gas flaring activities in the NDR of Nigeria is known to contribute significantly to the national, continental and global emissions, and therefore, the cause for the present study. The NDR houses the oil and gas reserves of the country and it is the stronghold of the country's economy and foreign exchange earnings for over four decades now. This region is the second largest mangrove forest in the world and it is famous for its exceptional bio-diversity. The NDR of Nigeria comprises of nine States and 185 Local Government Areas. The States include Delta, Rivers, Bayelsa, Imo, Abia, Akwa Ibom, Cross River, Edo and Ondo States. The NDR is a great flood plain which covers a $25,640 \mathrm{~km}^{2}$ of the Nigeria's land mass [23] with an estimated regional population of about 30 million people. It is the largest wetland and maintains the third-largest drainage basin in Africa [2]. The Niger Delta is an area of global significance for biodiversity conservation, due to its unusual biodiversity $[9,24]$. The area's biodiversity is under serious threat due to the rapid rate of environmental degradation occasioned by oil and gas exploration activities. NDR of Nigeria, the second largest delta in the world [25]; has more than 123 gas flaring sites [2].

\subsection{Data Collection and Data Processing}

For this present study, the data used were obtained from bulletins released on the website of Nigerian National Petroleum Corporation (NNPC) for information on gas production, gas flared and percent gas flared in Nigeria [20, 26-33]. The data collected was for a period of 25 years (1990 - 2014). The amounts of gas produced and gas flared for 25 years were converted from mscf (million standard cubic feet) to $\mathrm{mcm}$ (million cubic metre) and Microsoft Excel (2010) was used to analyse the data. Also, the correlation between the volumes of gas produced and the volumes of gas flared for the 25-year period was calculated and reported. In addition, the total and the average yearly volume of gas produced and gas flared for period under consideration was estimated.

\subsection{Data on Greenhouse Gas and Black Carbon Emissions}

Most of the inventories for pollutant emissions were estimated using emission factors and activity data [34]. Record on the quantity of emissions (GHGs and BC) emitted into the atmosphere from gas flaring activities in Nigeria is lacking in literature and this is part of the objectives of this present study. The data of the flared gas gathered from the aforementioned source were used to estimate the GHGs (carbon dioxide, methane and nitrous oxide) and BC emitted for the period of 25 years to study the country's progress on environmental sustainability in the Niger Delta as part of MDGs. The estimation of each GHG was carried out based on empirical method reported by the Association of Petroleum Institute (API) for the oil and gas industry [25] while that of BC was based on emission factor for gas flaring as reported in literature in relation to heating volume of natural gas of Nigeria origin [36].

The equations for estimating emissions from flares are:

$$
\begin{aligned}
& \mathrm{E}_{\mathrm{CO}_{2}}=\left(\mathrm{GF} \times \text { molar volume } \times \mathrm{MW}_{\mathrm{CO}_{2}} \times\right. \text { mass coversion } \\
& \times\left(\sum \left(\frac{\text { mole Hydrocarbon }}{\text { mole gas }}\right.\right. \\
& \text { A mole } \mathrm{C} \\
& \times \text { mole Hydrocarbon } \\
& \left.\times \frac{0.98 \text { mole } \mathrm{CO}_{2} \text { formed }}{\text { mole } \mathrm{C} \text { combusted }}\right) \\
& \left.+\frac{\mathrm{B} \text { mole } \mathrm{CO}_{2}}{\text { mole gas }}\right)
\end{aligned}
$$




$$
\begin{aligned}
\mathrm{E}_{\mathrm{CH}_{4}}=\mathrm{GF} \times \mathrm{CH}_{4} & \text { mole fraction } \times \% \text { residual } \mathrm{CH}_{4} \\
& \times \frac{1}{\text { molar volume }} \times \mathrm{MW}_{\mathrm{CH}_{4}} \\
\mathrm{E}_{\mathrm{N}_{2} \mathrm{O}}=\mathrm{GP} \times \mathrm{EF}_{\mathrm{N}_{2} \mathrm{O}} & \\
\mathrm{GHG} \text { emissions }= & \left(\left(1 \times \mathrm{CO}_{2} \text { emissions }\right)+(21\right. \\
& \left.\left.\times \mathrm{CH}_{4} \text { emissions }\right)\right) \\
& +\left(310 \times \mathrm{N}_{2} \mathrm{O} \text { emissions }\right)
\end{aligned}
$$

Emission factor $(\mathrm{BC})=0.0578(\mathrm{HV})-2.09$

$\mathrm{E}_{\mathrm{BC}}=$ Emission factor $\left(\mathrm{kg}\right.$ of $\left.\mathrm{BC} / 10^{3} \mathrm{~m}^{3}\right)$

$$
\times \mathrm{GF}\left(\mathrm{m}^{3}\right)
$$

$\mathrm{E}_{\mathrm{BC}}\left(\mathrm{tCO}_{2} \mathrm{e}\right)=\mathrm{E}_{\mathrm{BC}} \times 900$

Total Emissions $=\mathrm{GHG}$ emissions $+\mathrm{E}_{\mathrm{BC}}\left(\mathrm{tCO}_{2} \mathrm{e}\right)$ where:

$\mathrm{E}_{\mathrm{CO}_{2}}$ is the $\mathrm{CO}_{2}$ emissions (kg); $\mathrm{E}_{\mathrm{CH}_{4}}$ is the $\mathrm{CH}_{4}$ emissions (kg); $\mathrm{E}_{\mathrm{N}_{2} \mathrm{O}}$ is the $\mathrm{N}_{2} \mathrm{O}$ emissions (kg); $\mathrm{GF}$ is the Gas flared $\left(\mathrm{m}^{3}\right) ; \mathrm{E}_{\mathrm{BC}}$ is the Black carbon emissions $(\mathrm{kg})$; $\mathrm{E}_{\mathrm{BC}}\left(\mathrm{tCO}_{2} \mathrm{e}\right)$ is the Black carbon emissions (tons carbon dioxide equivalent); GHG Emissions is the Greenhouse gas emissions (tons carbon dioxide equivalent); Molar volume is the conversion from molar volume to mass (23.685 m³/kgmole); $\mathrm{MW}_{\mathrm{CO}_{2}}$ is the $\mathrm{CO}_{2}$ molecular weight; Mass conversion is the tonne/1000 kg; $A$ is the number of moles of carbon for the particular hydrocarbon; $\mathrm{B}$ is the moles of $\mathrm{CO}_{2}$ present in the flared gas stream;\% residual $\mathrm{CH}_{4}$ is the non-combusted fraction of flared stream; $\mathrm{MW}_{\mathrm{CH}_{4}}$ is the $\mathrm{CH}_{4}$ molecular weight; GP is the Gas produced $\left(\mathrm{m}^{3}\right)$; $\mathrm{EF}_{\mathrm{N}_{2} \mathrm{O}}$ is the $\mathrm{N}_{2} \mathrm{O}$ emission factor; and $\mathrm{HV}$ is the Heating volume of natural gas.

It is worth mentioning that the natural gas composition of Nigeria origin was employed in this work as reported in literature [37]. Heating volume of natural gas from Nigeria is $52.46 \mathrm{MJ} / \mathrm{m}^{3}$ (calculated from heating value of $37.23 \mathrm{MJ} / \mathrm{kg}$ ).

\subsection{Quantitative Uncertainty Analysis Procedure and Methods}

\subsubsection{Uncertainty Analysis Procedure}

The first step in the estimation of the uncertainty associated with the emissions (total emissions) from gas flaring operations in the NDR of Nigeria is the compilation and utilization of the volumes of GP and $\mathrm{GF}$ as the inputs in modelling the outputs $\left(\mathrm{CO}_{2}, \mathrm{CH}_{4}\right.$, $\mathrm{N}_{2} \mathrm{O}, \mathrm{BC}, \mathrm{GHGs}$ and total emissions). The second step is to establish the model, and this involves the use of the empirical formulae as provided in Equations (1 - 8) in the model. Thus, the most relevant parameters have been selected with some of them assumed as fixed parameters, which have less uncertainty. For this study, EasyFit $\AA^{\circledR} \quad 5$ (evaluation version) was employed to fit the input data (GP and GF) into the appropriate probability distribution function while Analytica® (4.5) software was used for modelling the uncertainty of the emission estimate. Thereafter, the probability distribution models of the input parameters (GP and GF) were developed as model inputs. The probability distributions may be empirical, parametric or combinations of both. In all, the procedure entails having the input models, propagations of uncertainty from input parameters to model outputs which can be estimated using Monte Carlo simulation (MCS) or Latin hypercube sampling (LHS) which is a Tier 2 method recommended in 2006 Guidelines for National Greenhouse Gas Inventories [38]. Finally, the quantitative or numerical estimates of the uncertainty associated with GHGs, BC and total emissions resulting from gas flaring were determined.

\subsubsection{Methods for Simulating Uncertainty Propagation}

A numerical simulation method, LHS, was used for simulating the propagation of probability distributions of all inputs using a model based on simulated random sampling in this study. Presently, both MCS and LHS are the most generally used numerical simulation methods. In MCS, a model is run repeatedly, using different values for each of the uncertain input parameters each time. The values of each of the uncertain input parameters are randomly generated based on the probability distributions for the parameters. In this present work using Analytica ${ }^{\circledR}$, Minimal Standard which is the default method was used as random number generator. The benefit of using MCS is that it can afford an excellent approximation of the output distribution with a sufficient sample size. The disadvantage is that it may be necessary to use large sample sizes to obtain a smooth approximation of the probability distribution function. In LHS, the values of each uncertain input are not randomly generated. Instead, the probability distribution is first divided into ranges of equal probability, and then one sample is taken from each range [39]. For some applications with a given simulation sample size, LHS is a more precise numerical simulation method than MCS [39]. In the Analytica ${ }^{\circledR}$, median Latin hypercube is preferred to 
random Latin hypercube due to its high accuracy that is why it is set as the default sampling method.

\subsection{Sensitivity Analysis}

Sensitivity analysis is used to identify the major sources of the uncertainty from the model inputs. The results of the analyses helps the decision-makers in confirming the major contributors to the uncertainty in the model output, and in deciding where additional data collection may be needed in reducing uncertainty in the model input. In this study, sensitivity analysis was conducted on the input models to ascertain the parameter which significantly influence the emission of GHGs via flaring of gas.

\section{RESULTS AND DISCUSSION}

\subsection{Analysis of Gas Produced and Flared}

Figure 1 shows the volume of GP and volume of GF from 1990 to 2014.At the start of 1990, the volume of GP was $28.43 \mathrm{bcm}$ and this increased gradually to $59.28 \mathrm{bcm}$ in 2005. This volume of GP is more than double the value as at 1990 (Figure 1). A considerable increase in the volume of GP was noticed from 2005 to 2007 with 2007 (84.71 bcm) being the peak of gas production for the 25-yearperiod in focus (Figure 1). Gas production decreased rapidly from 2007 to 2009 $(64.88 \mathrm{bcm})$ and then decreased slightly in 2013 to a volume of $61.64 \mathrm{bcm}$ with a sharp increase in 2014 $(72.96 \mathrm{bcm})$. For this period, a yearly average of $52.02 \mathrm{bcmof}$ gas was produced.

The volume of GF in the year 1990 was $22.40 \mathrm{bcm}$, which was relatively steady between $22.36 \mathrm{bcm}$ in 1999 and $25.58 \mathrm{bcm}$ in 2006 (Figure 1). For the period in view, year 2006 recorded the highest amount of GF. A sharp decrease in GF was observed from 2006 to 2014 with 2014 recording the lowest amount of GF which was $11.27 \mathrm{bcm}$. A difference of $11.14 \mathrm{bcm}$ was calculated for the volume of GF in 1990 and 2014, with the period recording an average of $22.23 \mathrm{bcm}$ of GF on yearly basis. Total amount of GP and GF for this 25-year duration was $1.30 \mathrm{tcm}$ and
$555.74 \mathrm{bcm}$, respectively. This shows that $57.26 \%$ of the GP was flared. In monetary terms, $\$ 58.91$ Billion $(\$ 3 / 1000 \mathrm{scf}=\$ 0.106 / \mathrm{cm})$ of gas was burnt up in flame in 25 years which translates to annual resource wastage of $\$ 2.36$ Billion. The difference observed between the volume of GP and the volume of GF is a measure of the volume of gas utilized and this is presented in Figure 1. For the period in view, the year 2014 witnessed the peak of gas utilization and also recorded the lowest amount of GF in recent times (Figure 1). The correlation between data of GP and GF is estimated to be -0.36 , which indicates a weak and negative relationship between them. Also, the analysis of variance test conducted on the data (GP and GF) show that they are not statistically equal ( $F_{\text {critical }}$

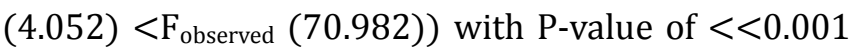
at $95 \%$ confidence interval.

\subsection{Analysis of Emissions from Flared Gas}

The amounts of GHGs and BC emitted through gas flaring activities in the NDR of Nigeria were estimated for the 25-year period using Equations 1-4 and 5-7, respectively. Emission factor of $\mathrm{BC}$ was calculated to be $0.942 \mathrm{~kg}$ of $\mathrm{BC} / 10^{3} \mathrm{~m}^{3}$ for gas flaring activities as reported in literature [36] and this value is specifically for this present study. Figures 2 and 3 show the emission values of $\mathrm{CO}_{2}, \mathrm{CH}_{4}$ and $\mathrm{N}_{2} \mathrm{O}$, and $\mathrm{BC}$ and GHGs from 1990 to 2014, respectively.

\subsubsection{Greenhouse Gases Emissions}

Figure 2shows the amounts of individual GHG emitted into the environment from 1990 to 2014. As can be noticed in Figure 1 for the volume of GF, the same pattern is observed for the amounts of $\mathrm{CO}_{2}$ released into the NDR. This is due to the linear relationship between the volume of GF and the quantity of $\mathrm{CO}_{2}$ emitted as expressed in Equation (1).The quantity of $\mathrm{CO}_{2}$ emitted in 1990 was $4.67 \times 10^{7}$ tons while that in 2014 was $2.35 \times 10^{7}$ tons, with the maximum $\mathrm{CO}_{2}$ emission in 2006 estimated to be $5.96 \times 10^{7}$ tons (Figure 2).

Table 1: Uncertainties of Gas Flaring Emissions (1990-2014) in the NDR of Nigeria (number of trails $=2000)$

\begin{tabular}{|c|c|c|c|c|c|c|}
\hline Emission & & Simulated & Max. & \multicolumn{2}{|c|}{ Relative uncertainty } & Estimated \\
\hline $\mathrm{CO}_{2}$ & $3.065 \mathrm{M}$ & $39.31 \mathrm{M}$ & $59.42 \mathrm{M}$ & $-92.20 \%$ & $51.16 \%$ & $41.53 \mathrm{M}$ \\
\hline $\mathrm{N}_{2} \mathrm{O}$ & 0.654 & 1.209 & 1.948 & $-45.91 \%$ & $61.12 \%$ & 1.166 \\
\hline $\mathrm{CH}_{4}$ & $17.940 \mathrm{~K}$ & $230.1 \mathrm{~K}$ & $347.8 \mathrm{~K}$ & $-92.20 \%$ & $51.15 \%$ & $243.1 \mathrm{~K}$ \\
\hline GHGs & $3.514 \mathrm{M}$ & $45.06 \mathrm{M}$ & $68.12 \mathrm{M}$ & $-92.20 \%$ & $51.18 \%$ & $47.61 \mathrm{M}$ \\
\hline BC & $1.385 \mathrm{M}$ & $17.76 \mathrm{M}$ & $26.84 \mathrm{M}$ & $-92.20 \%$ & $51.12 \%$ & $18.76 \mathrm{M}$ \\
\hline Total & $4.899 \mathrm{M}$ & $62.82 \mathrm{M}$ & $94.96 \mathrm{M}$ & $-92.20 \%$ & $51.16 \%$ & $66.36 \mathrm{M}$ \\
\hline
\end{tabular}




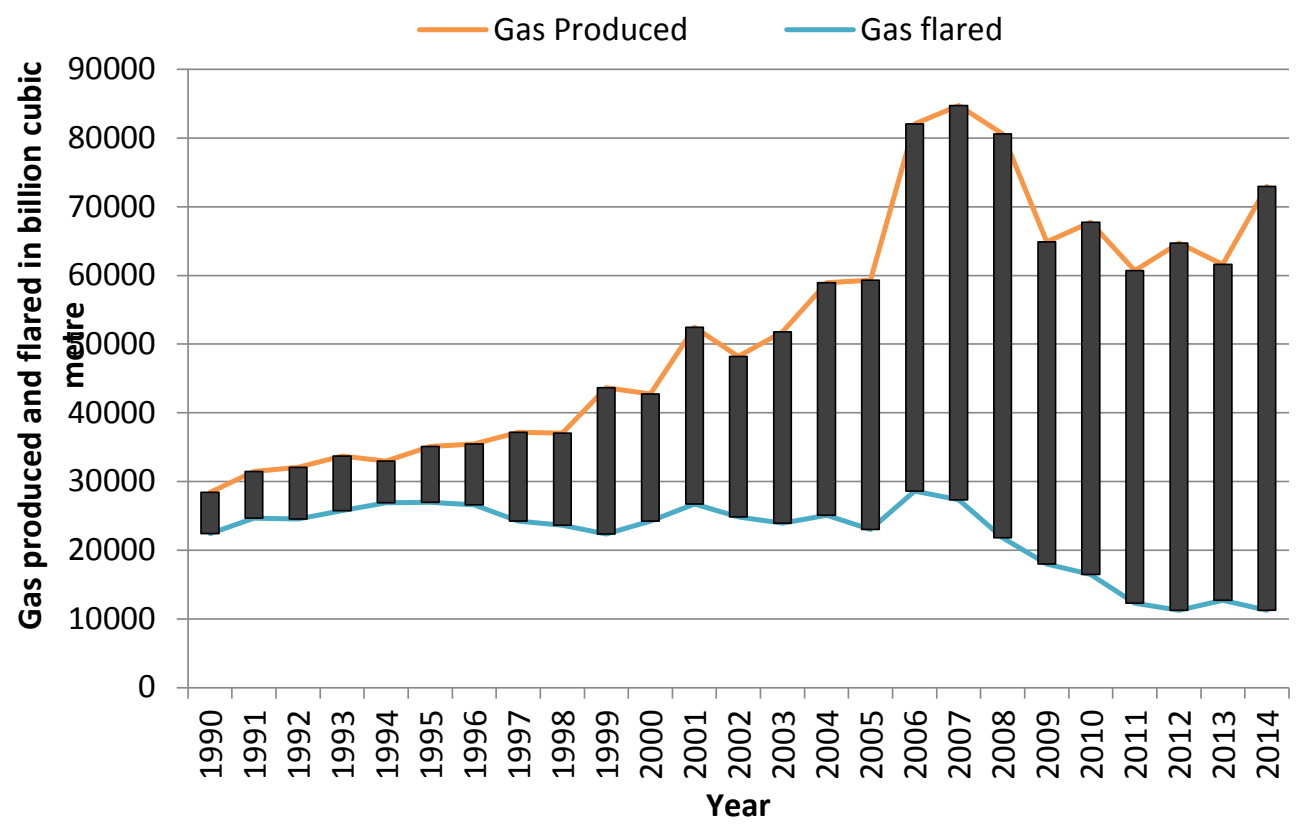

Figure 1: Graph of Gas Produced and Gas Flared Indicating Gas Utilization

Total amount of $\mathrm{CO}_{2}$ released in the NDR from 1990 to 2014was 1.16 × $10^{9}$ tons. Figure 2 shows a noteworthy reduction in $\mathrm{CO}_{2}$ emission (60.6\%) from its peak in 2006 to its lowest value in 2014 (2.35 x 107 tons).

It is observed in Figure 2 that $\mathrm{CH}_{4}$ emissions follow similar pattern as that of $\mathrm{CO}_{2}$ emissions while $\mathrm{N}_{2} \mathrm{O}$ emissions for the period in view is different. This distinct pattern shown for $\mathrm{N}_{2} \mathrm{O}$ emissions emanated from Equation (3), which involves the GP parameter as against the $\mathrm{GF}$ variable for $\mathrm{CO}_{2}$ and $\mathrm{CH}_{4}$ emissions as provided in Equations(1 and 2). The amount of $\mathrm{CH}_{4}$ released into the atmosphere in the NDR were $2.74 \mathrm{x}$ $10^{5}, 3.49 \times 10^{5}$ and $1.38 \times 10^{5}$ tons in 1990, 2006 and 2014 , respectively (Figure 2). For the quantity of $\mathrm{N}_{2} \mathrm{O}$ released, 0.65 tons was recorded in 1990 which increased moderately to 1.95 tons in 2007 and decreased gradually to 1.68 tons in 2014 (Figure 2). Total emission of $\mathrm{CH}_{4}$ and $\mathrm{N}_{2} \mathrm{O}$ for the 25-year period was estimated to be $6.79 \times 10^{6}$ tons and 29.91 tons, respectively (Figure 2).

The total quantity of GHGs $\left(1.16 \times 10^{9}\right.$ tons of $\mathrm{CO}_{2}$, $6.79 \times 10^{6}$ tons of $\mathrm{CH}_{4}$ and 29.91 tons of $\mathrm{N}_{2} \mathrm{O}$ ) released in the NDR for the 25-year period was $1.33 \times 10^{9}$ tons of $\mathrm{CO}_{2}$ equivalent $\left(\mathrm{tCO}_{2}\right.$ e) (Figure 2). The cost implication of flaring $555.74 \mathrm{bcm}$ of gas in the NDR in terms of GHG emissions was $\$ 19.94$ billion (at $\$ 15$ per ton carbon credit tax). From Figure 3, the total amount of GHGs also demonstrated the same pattern as that of the GF and other emissions dependent on the amount of GF.

\subsubsection{Black Carbon Emissions}

Figure 3 illustrates the $\mathrm{BC}$ emissions from gas flaring operations in the NDR for 25 years. Since BC estimation depends on the volume of GF as expressed in Equation (6), the same pattern was observed between the amounts of BC emitted and the volume of GF.

At the start of the period in view, $2.11 \times 10^{4}$ tons of BC was released into the atmosphere of the NDR with maximum amount of BC emitted in the year 2006 and $1.06 \times 10^{4}$ tons released in 2014 (Figure 3).The total $\mathrm{BC}$ emission witnessed in this region in 25 years amounted to $5.24 \times 10^{5}$ tons, which translates to 4.71 $\mathrm{x} 10^{8} \mathrm{tCO}_{2}$ e. Carbon credit tax estimation of this emission value was found to be $\$ 7.07$ Billion (at $\$ 15$ per ton as carbon credit tax).

\subsection{Total Estimated Emission}

The total estimated emission (GHGs and BC) from gas flaring activities in the NDR during the period in view amounts to $1.80 \times 10^{9} \mathrm{tCO}_{2}$ e from the burning of $555.74 \mathrm{bcm}$ of gas. The trend of the total emissions from 1990 to 2014 is presented in Figure 3 and this is similar with those of BC emissions and GHGs emissions. The GHGs emission costs \$19.94 Billion while the $\mathrm{BC}$ emission was estimated to be $\$ 7.07$ Billion. For this 25 years of GHGs and BC emissions in the NDR, the total economic cost amounts to $\$ 85.92$ Billion. This value consists of the cost of gas flared (\$58.91 Billion) and the cost of emissions (\$27.01 Billion) released into the atmosphere. 


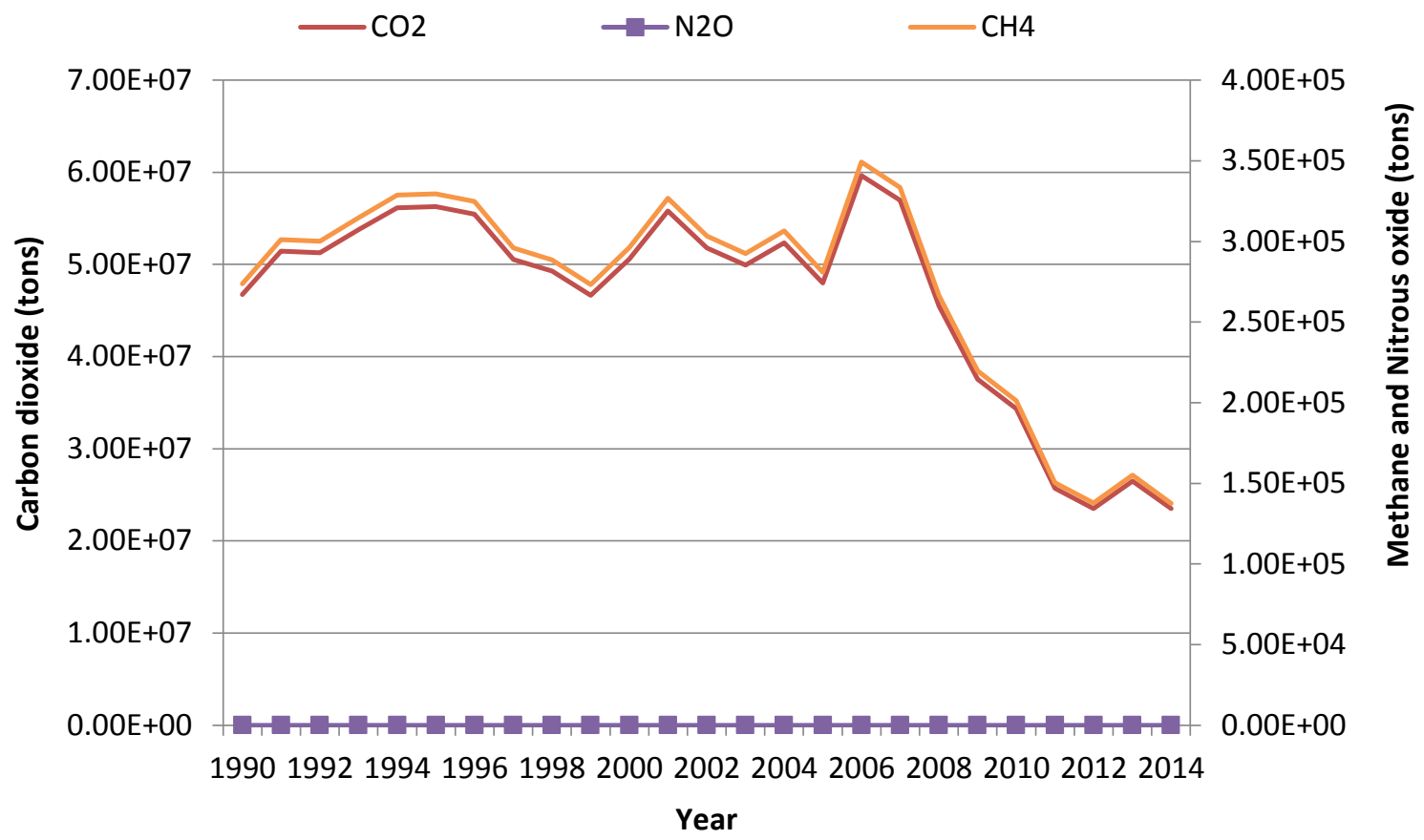

Figure 2: Graph of $\mathrm{CO}_{2}, \mathrm{CH}_{4}$ and $\mathrm{N}_{2} \mathrm{O}$ Emissions

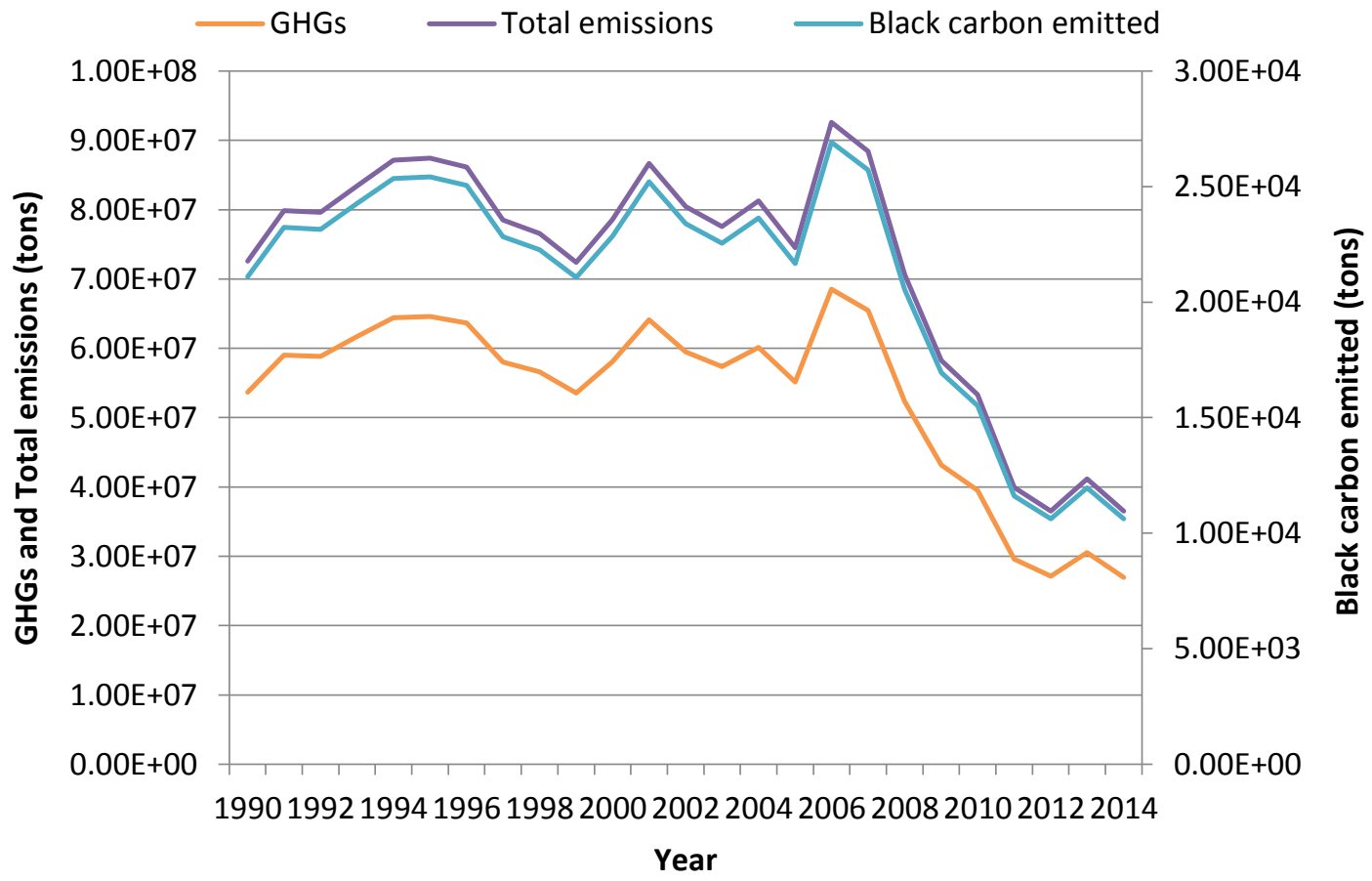

Figure 3: Graph of GHGs, BC and Total Emissions

3.4 Uncertainty Analysis

\subsubsection{Quantitative Uncertainty Analysis for the Mean of Total Emissions}

Of the two approaches - Tier 1 and Tier 2 recommended for developing quantitative estimates of uncertainty in the inventory estimate of individual source categories, the Tier 2 approach is both more flexible and reliable than Tier 1 [38]. Other reasons that informed the choice of Tier 2 approach for this study is the coefficient of variation (ratio of the standard deviation to the mean) associated with the input variables which was more than $0.3(0.52)$ and the not normal distribution of the input variables. Goodness-of-fit tests (Chi-Squared test, Kolmogorov- 
Smirnov test, and Anderson-Darling test) conducted on the input parameters (GP and GF) using Easy Fit $®$ assigned beta and triangle distribution to GP and GF, respectively. Finally, based on this distribution, the range of the mean of the total emissions (GHGs and BC) at $95 \%$ confidence was obtained by running the simulation involving both the input and output models on Analytica ${ }^{\circledR}$.

Figure 4 provides the influence diagram developed to model the estimation of the uncertainty associated with this study using Analyticaß. Each sample was obtained using the same sample size as the original observed data set, and then the mean was calculated. These means describe a probability distribution for statistics from which probability ranges were deduced. Table1 gives the mean (simulated), relative uncertainties of the mean, lower and upper confidence levels of the mean for the quantity of GHGs, BC and total emissions released into the Niger Delta environment due to flaring of gas. The estimated mean of GHGs, BC and total emissions obtained prior to quantifying the uncertainties associated with them was found to be relatively higher than that obtained for the simulated mean as presented in Table 1. This discrepancy in the mean of GHGs, BC and total emissions may be attributed to the nature and statistical distribution of the input data, the collection and mode of collection of the data by the oil companies operating in the country, who are the sole providers of these data.

It is worth mentioning that the running of the simulation model involved 250, 500, 1000 and 2000 iterations. For this work, the simulation with 2000 iterations was observed to give the best result for the emission model output. All of this was obtained using the median LH.

\subsubsection{Estimating Uncertainty in the Model Output}

In the emission (output) model, uncertainties from GP and GF were propagated to estimate the amounts of $\mathrm{CO}_{2}, \mathrm{CH}_{4}, \mathrm{~N}_{2} \mathrm{O}, \mathrm{BC}$, GHGs and total emissions based on the equations used in the model. Random samples were generated using median LH method on the Analytica ${ }^{\circledR}$. The range of uncertainties of GHGs, BC and total emissions is shown in Figures 5-7, respectively. The mean values are $3.93 \times 10^{7}$ tons, 2.30 $\times 10^{5}$ tons, 1.209 tons, $1.78 \times 10^{7} \mathrm{tCO}_{2}$ e, $4.51 \times$ $10^{7} \mathrm{tCO}_{2}$ e and $6.28 \times 10^{7} \mathrm{tCO}_{2}$ e for $\mathrm{CO}_{2}, \mathrm{CH}_{4}, \mathrm{~N}_{2} \mathrm{O}, \mathrm{BC}$, GHGs and total emissions, respectively (Table 1 ). As observed in Table 1, the range of total GHGs is between $6.45 \times 10^{6}$ tons and $6.65 \times 10^{7}$ tons at the 95 percent confidence interval which corresponds to relative uncertainties of $-92.20 \%$ and $51.16 \%$. The relative uncertainties associated with $\mathrm{CO}_{2}, \mathrm{CH}_{4}, \mathrm{~N}_{2} \mathrm{O}$ and $\mathrm{BC}$ emissions are also presented in Table 1. Comparison of these results with what was previously reported $\left( \pm 75 \%\right.$ for $\mathrm{CO}_{2}$ and $\mathrm{CH}_{4} ;-10 \%$ to $1000 \%$ for $\mathrm{N}_{2} \mathrm{O}$ )in literature shows that the lower limits of $\mathrm{CO}_{2}$, $\mathrm{CH}_{4}$ and $\mathrm{N}_{2} \mathrm{O}$ are slightly outside the values specified while the upper limits are well within the set limits, especially, for $\mathrm{N}_{2} \mathrm{O}$ [35].

\subsubsection{Sensitivity Analysis on Emissions from Gas Flaring Activities}

The Tornado chart as represented by Figure 8 shows the sensitivity of total emissions released in the gas flaring activities of NDR. It can be observed that out of the two main parameters (GF and GP) that contribute to the estimation of emissions, $\mathrm{GF}$ is more sensitive to the uncertainty of the total emissions (Figure 8). The result of the sensitivity analysis indicates that the most effective way to reduce uncertainty in the estimated total emissions is to reduce uncertainty in the data of GF with more accurate data collection and the use of state-of-the-art instruments.

\subsection{Environmental Sustainability Consideration}

No region in Nigeria is experiencing such an extent of environmental degradation as witnessed in the NDR of the country. Gas flaring is known to release numerous harmful gases and particles which have polluted the environment in many ways. Soil, water and air in the region is gravely polluted by this singular act of gas flaring and has seriously affected the livelihood and well-being of the inhabitants, especially, those living close to the flaring sites [2]. Building roofs, walls, and other structures are corroded by the emissions from gas flaring operations [8]. The ecosystem, atmosphere, economy and public health are adversely affected by this exercise, leaving the people of the region poor and hungry, unhealthy, lacking drinking water and good sanitation, and basic social amenities.

Proffering a lasting solution to the problem of nonstop gas flaring in the region will go a long way in curbing the ecological destruction and environmental degradation presently witnessed in the NDR of Nigeria, in order to ensure and promote environmental sustainability. 


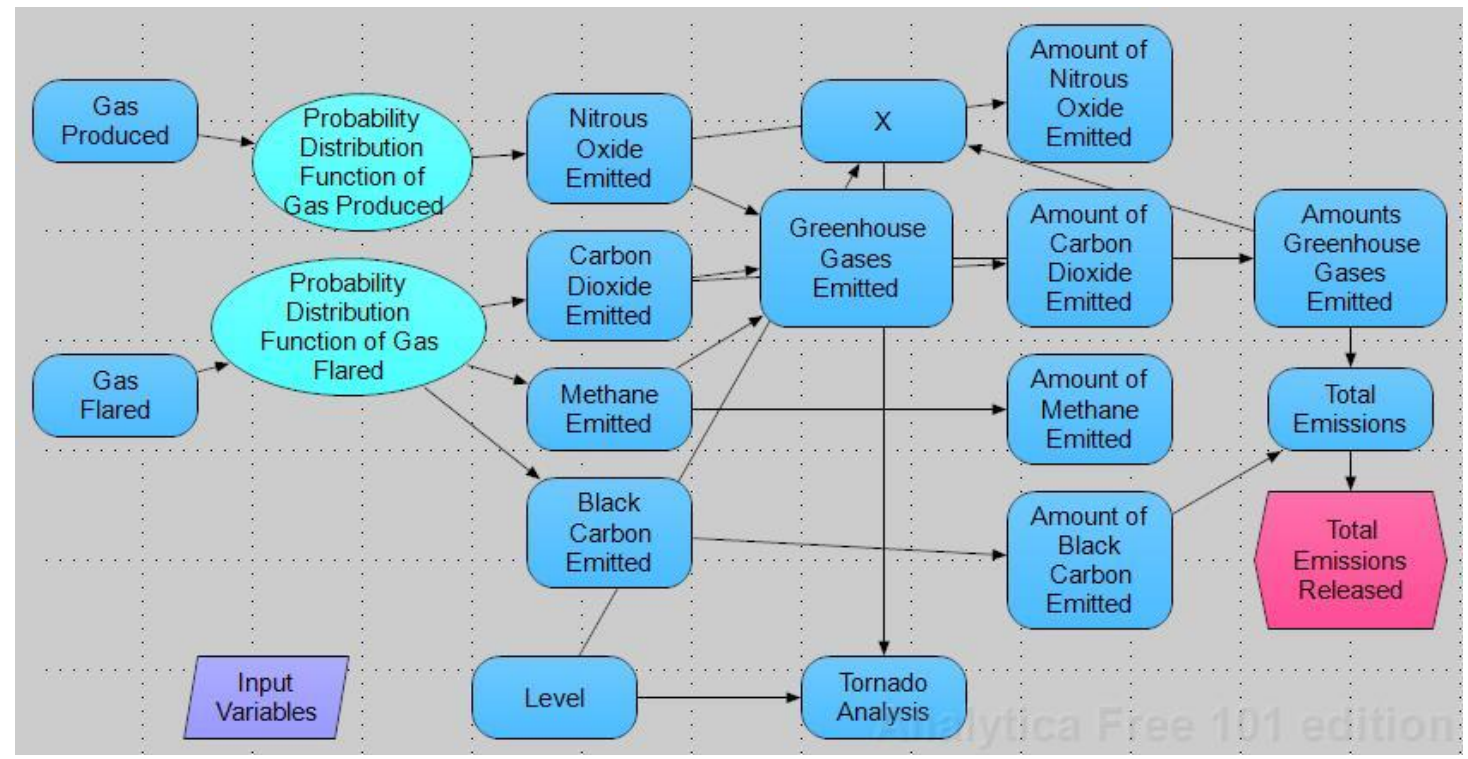

Figure 4: Influence Diagram Used to Model the Uncertainty Estimates

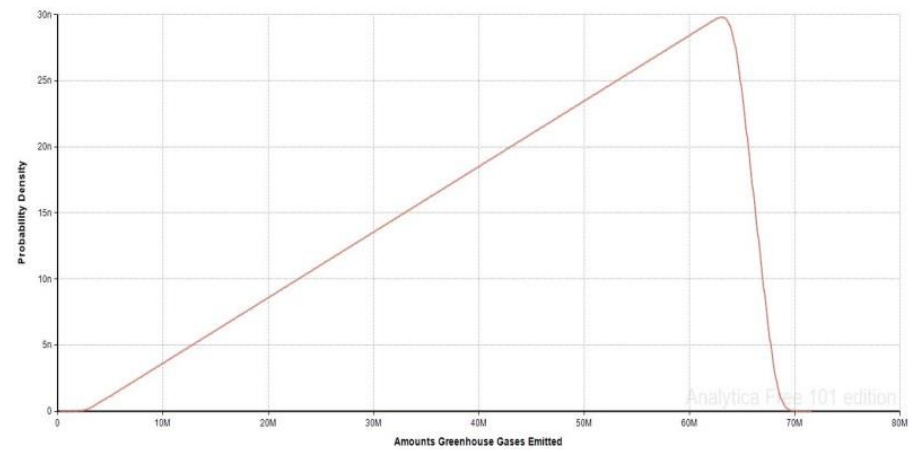

Figure 5: Cumulative Probability of GHGs Emitted

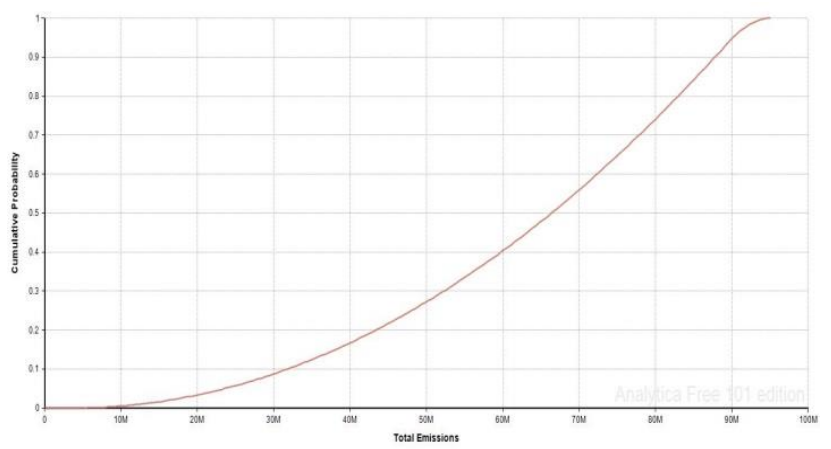

Figure 7: Cumulative Probability of Total Emissions Released

Subject to the aforementioned, the progress on Goal 7 (ensure environmental sustainability), Target 9 (reversing loss of environmental resources), indicator 28 (emissions) of the MDG in the NDR was studied and a significant reduction in the emissions from the gas flaring activities in the region was observed. The quantity of emissions released into the environment in the years 1990 and 2014 were estimated to be 7.26 $\mathrm{x} 10^{7}$ and $3.65 \times 10^{7} \mathrm{tCO}_{2} \mathrm{e}$, respectively. These results indicate a significant reduction in emissions by $3.61 \mathrm{x}$

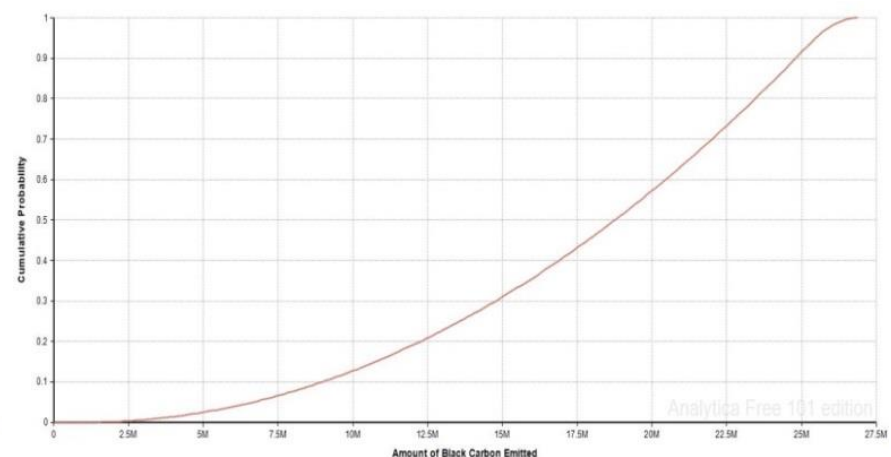

Figure 6: Cumulative Probability of BC Emitted

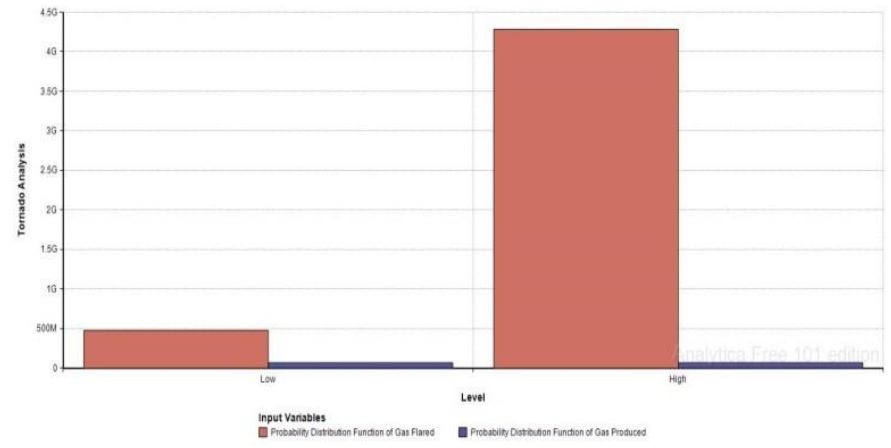

Figure 8:Tornado Graph of Sensitivity of Input Parameters

$10^{7} \mathrm{t} \mathrm{CO}_{2}$ e (50.0\%). For GHGs and BC emissions, substantial reduction by $49.71 \%$ and $49.67 \%$, which correspond to $2.66 \times 10^{7}$ and $9.44 \times 10^{6} \mathrm{tCO}_{2} \mathrm{e}$, respectively, were recorded. Worthy of note is the fact that no benchmark is given in the indicator 28 of the MDG to measure the success and compliance of Goal 7, Target 9. The result obtained from this study is a pointer to the promotion of environmental sustainability, especially in the NDR as set by the MDG 7 , Target 9 and indicator 28 . The latter centres on the 
reduction of emissions discharged into the atmosphere thereby preserving the environment, ecosystem, natural resources, and consequently fulfilling the purpose of MDG.

The above values demonstrate a considerable progress in the pursuit of the government of Nigeria towards achieving the Goal 7, Target 9 and indicator 28of the MDG as it applies to the NDR, which is renowned for devastating environmental degradation. Increased utilization of natural gas in the country due to the various government policies and infrastructural developments in the gas sector of the economy have helped reduce gas flaring by reducing the amount of flared gas. Percent gas flared in the country has reduced from over $95 \%$ in the 1960 s to over $70 \%$ in the 1990 s and to $15.28 \%$ in 2014 [15]. The NDR of the country is notorious for continuous gas flaring activities for over four decades with the experience of unquantifiable negative impact on the ecosystem, environment, socio-economic and human public health. Ensuring environmental sustainability in this part of the nation is very important because of the peculiar nature and endowment of the region. Above all, environmental sustainability in the NDR as set by the MDG 7 will positively affect the livelihood and well-being of the over 30 million people in this part of the country.

To this effect, there is the desperate need for Nigeria to either completely stop gas flaring or reduce it to the barest minimum, and this can be achieved by the development of domestic market and gas infrastructure to encourage increased utilization of natural gas. This will considerable improve environmental sustainability in the NDR in line with MDG 7, Target 9 and indicator 28. Also, natural gas should be monetized to diversify the economy in order to increase foreign earnings. In addition, the final drafting and passing into law of the petroleum industry bill (PIB) in Nigeria will significantly assist in the development of the gas sector of the economy.

\section{CONCLUSION}

Over five decades of gas flaring in the NDR of the country is responsible for the unjustifiable destruction of ecological system, degradation of environment, poverty, unrest, erosion, serious health problems, and climate change and its effects. Results obtained from this study revealed that the quantity of emissions (GHGs and BC) released into the NDR's environment due to gas flaring activities has reduced by approximately $50 \%$ in 2014 compared to 1990 . This can be attributed to sustained gas utilization on the part of the Nigerian government to curb gas flaring despite the increase in GP. Goal 7, Target 9 (reverse of loss environmental resources) of the MDGs on sustainable environment in 2014 compared to that of 1990 seems progressing well in the NDR, despite no recommended criterion to measure its level of success. This is a right step in the right direction in ensuring environmental sustainability in the NDR in accordance with the MDG 7.

\section{REFERENCES}

[1] Orimoogunje OOI, Ayanlade A, Akinkuolie TA, Odiong AU. Perception on effect of gas flaring on the environment. Research Journal of Environmental and Earth Sciences 2(4), 188-193 (2010).

[2] Tawari CC, Abowei JFN. Air pollution in the Niger Delta Area of Nigeria. Intl. J. Fisheries Aquatic Sci. 1, 94-117 (2012).

[3] World Bank, 2007. A Twelve Year Record of National and Global Gas Flaring Volumes Estimated Using Satellite Data Final Report. Available at http://siteresources.world bank.org/INTGGFR/ Resources/DMSP_flares_20070530_b-sm.pdf

[4] Ologunorisa TE. A review of the effects of gas flaring on the Niger Delta environment. Int. Sustain. Dev. World Ecol. 8, 249-255 (2001).

[5] Elvidge DC, Ziskin D, Baugh KE, Tuttle TB, Ghosh T, Pack WD, Erwin HE, Zhizhin MA. Fifteen year record of global natural gas flaring derived from satellite data. Energies 2, 595-622 (2009).

[6] Bassey N. Gas flaring: Assaulting communities, jeopardizing the world. A paper presented at the National Environmental Consultation hosted by the Environmental Rights Action in conjunction with the Federal Ministry of Environment at Reiz Hotel, Abuja 10-11 December 2008.

[7] Giwa SO. 2014. Baseline black carbon emission inventory for gas flaring in the Niger Delta region of Nigeria. LAP LAMBERT Academic Publishing, Heinrich-Bocking-Str. 6-8, 66121 Saarbruken, Germany. ISBN: 978-3-659-57233-3.

[8] Nkwocha EE, Pat-Mbano EC. Effect of gas flaring on buildings in the oil producing rural communities of River State, Nigeria. African Research Review 4 (2), 90-102 (2010).

[9] World Bank. Defining an environmental development strategy for the Niger Delta, vol. 11. (1995) (World Bank, New York)

[10] Ukala E. Gas flaring in Nigeria's Niger Delta: Failed promises and reviving community voices. $J$. Energy, Climate Environ. 97, 97-126 (2011).

[11] Farina A. Global Gas Flaring Reduction PublicPrivate Partnership. Washington D.C. Available at http://web.worldbank.org/WBSITE/EXTERNAL/N EWS/0/contentMDK:4 607,00.html (visited last on $27 / 09 / 2015)$ 
[12] Dung JE, Bombom SL, Agusomu DT. The effects of gas flaring on crops in the Niger Delta, Nigeria. Geo. J. 73, 297-305 (2008).

[13] World Bank, 2002. Report on Consultations with Stakeholders. World Bank-GGFR Report 1. Global Gas Flaring Reduction Public-Private Partnership. Washington, D.C. (visited last on 13/04/15).

[14] Bond TC, Doherty SJ, Fahey DW, Forster PM, Berntsen T, DeAngelo BJ, et al. Bounding the role of black carbon in the climate system: A scientific assessment. J. Geophy. Resear. Atmospheres. 118, 5380-5552 (2013)

[15] Giwa So, Adama 00, Akinyemi 00. Baseline black carbon emissions for gas flaring in the Niger Delta region of Nigeria. J. Nat. Gas Sci. Engrg. 20, 373-379 (2014).

[16] Enabudoso EJ, Gharoro EP, Ikena GO, Abhulimhen-Iyoha B. Health and the Millennium Development Goals. The Nigerian Perspective. Benin Journal of Postgraduate Medicine 8 (1), 1-7 (2006).

[17] Ojeh VN. Sustainable development and gas flaring activities: a case study of Ebedei area of Ukwuani LGA, Delta State, Nigeria. Resources and Environment 2(4), 169-174, 2012.

[18] Lawal AI, Obasaju B, Rotimi EM. Towards achieving millennium development goals (MDG) in Nigeria: prospect and challenges. Journal of Economics and Sustainable Development 3 (9), 7482 (2012)

[19] Centre for Democracy and Development (CDD), The millennium development goals and poverty reduction in Nigeria: progress, prospects and policy implications. Final report, 2013.s

[20] National Bureau of Statistics (NBS), 2013. Millennium Development Goals Performance Tracking Survey Report 2012.

[21] Idris-Nda A, Dodo U, Jimada AM. Challenges facing the attainment of the millennium development goals (MDG's) in the water sector: the Niger State example, central Nigeria. Journal of Scientific Research and Reports 3 (7), 973-984 (2014).

[22] Olabode KT, Adeigbe YK, Zaggi YH, Owonibi E. Millennium development goals (MDGs) in Nigeria: issues and problems. Global Journal of HumanSocial Science: C Sociology and Culture 14 (5), 4253 (2014).

[23] Akinniyi JA. Achieving environmental improvement in the Niger-Delta area of Nigeria. The Coconut - A Multidisciplinary Journal of Environment, Science, Agriculture and Technology 1 (1), 145-154 (2010).

[24] Ugochukwu CNC, Ertel J. Negative impacts of oil exploration on biodiversity management in the Niger Delta area of Nigeria. Impact assessment and project appraisal 26(2), 139-147 (2008).

[25] Odukoya OA. Oil and sustainable development in Nigeria: A case study of the Niger Delta. J. Hum.
Ecol. 20, 249-258 (2006).

[26] Nigerian National Petroleum Corporation (NNPC), 1997. Annual Statistical Bulletin. Corporate Planning and Development Division (CPDD). January-December 1997.

[27] Nigerian National Petroleum Corporation (NNPC), 2008. Annual Statistical Bulletin. Corporate Planning and Development Division (CPDD). January-December 2008.

[28] Nigerian National Petroleum Corporation (NNPC), 2009. Annual Statistical Bulletin. Corporate Planning and Development Division (CPDD). January-December 2009.

[29] Nigerian National Petroleum Corporation (NNPC), 2010. Annual Statistical Bulletin. Corporate Planning and Development Division (CPDD). January-December 2010.

[30] Nigerian National Petroleum Corporation (NNPC), 2011. Annual Statistical Bulletin. Corporate Planning and Development Division (CPDD). January-December 2011.

[31] Nigerian National Petroleum Corporation (NNPC), 2012. Annual Statistical Bulletin. Corporate Planning and Development Division (CPDD). January-December 2012.

[32] Nigerian National Petroleum Corporation (NNPC), 2013. Annual Statistical Bulletin. Corporate Planning and Development Division (CPDD). January-December 2013.

[33] Nigerian National Petroleum Corporation (NNPC), 2014. Annual Statistical Bulletin. Corporate Planning and Development Division (CPDD). January-December 2014.

[34] Zhou Y, Cheng S, Chen D, Land J, Zhao B, Wei W. A new statistical approach for establishing highresolution emission inventory of primary gaseous air pollutants. Atmos. Environ. 94, 392-401 (2014).

[35] API. Compendium of greenhouse gas emissions methodologies for the oil and natural gas industry. American Petroleum Institute, 2009.

[36] McEwen JDN, Johnson MR. Black carbon particulate matter emission factors for buoyancy driven associated gas flares. J. Air Waste Manage. Assoc. 62(3), 307-321, 2012.

[37] Rahmouni C, Tazerout M, Corre OL. Determination of the combustion properties of natural gases by pseudo-constituents. Fuel 82, 1399-1409 (2003).

[38] Marland E, Cantrell J, Kiser K, Marland G, Shirley $\mathrm{K}$. Valuing uncertainty part $\mathrm{I}$ : the impact of uncertainty in GHG accounting. Carbon Management 5(1), 35-42 (2014).

[39] Lu Y, Huang Z, Zhang T. Method and case study of quantitative uncertainty analysis in building energy consumption inventories. Energy and Buildings 57, 193-198 (2013). 